\title{
Penggunaan Metode Peta Pikiran untuk Meningkatkan Kemampuan Menulis Resensi Novel
}

\author{
Olivia Juni Rosita Hutagalung ${ }^{*}$ \\ ${ }^{1}$ Jurusan Pendidikan Bahasa Indonesia, Universitas Pendidikan Ganesha, Singaraja, Indonesia
}

\section{ART I CLE I N F O}

Article history:

Received July 16, 2021

Revised July 25, 2021

Accepted October 20, 2021

Available online November 25, 2021

Kata Kunci:

Metode Peta Pikiran, Hasil Belajar, Resensi Novel

\section{Keywords:}

Mind Map Method, Learning

Outcomes, Novel Review

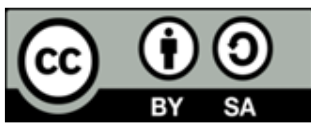

This is an open access article under the CC BY-SA license.

Copyright (ㄷ) 2021 by Author. Published by Universitas Pendidikan Ganesha.

\begin{abstract}
A B S T R A K
Meresensi sebuah novel merupakan salah satu bahan ajar yang dibelajarkan untuk melatih kemampuan menulis serta meningkatkan minat siswa. Hanya saja tidak semua siswa mampu meresensi novel dengan baik. Tujuan penelitian ini adalah untuk meningkatkan hasil belajar menulis resensi novel peserta didik dengan menggunakan metode pembelajaran peta pikiran. Penelitian ini merupakan penelitian tindakan kelas yang dilaksanakan dalam dua siklus penelitian. Tiap siklus penelitian terdiri dari empat tahapan yakni perencanaan, pelaksanaan tindakan, observasi, evaluasi, dan refleksi. Subjek yang terlibat dalam penelitian ini yakni 32 orang siswa kelas XI SMA. Pengumpulan data dalam penelitian dilakukan dengan menggunakan metode observasi, wawancara, angket, dan tes. Instrumen penelitian berupa lembar observasi dan lembar tes kemampuan menulis siswa. Data yang diperoleh dalam penelitian ini dianlisis dengan menggunakan teknik analisis deskriptif kualitatif menggunakan rumus persentase. Hasil yang diperoleh pada penelitian ini menunjukkan bahwa pada siklus I sebanyak 17 peserta didik lulus $\mathrm{KKM}$ / tuntas atau $53 \%$ peserta didik mendapat nilai di atas KKM (82) dan 15 peserta didik tidak lulus KKM/ tidak tuntas karena mendapatkan nilai dibawah nilai KKM (82). Dengan demikian, indikator keberhasilan belum tercapai, sehingga perlu dilanjutkan pada siklus II. Hasil siklus II diperoleh bahwa dari 32 peserta didik yang mengikuti tes, maka sebanyak 30 peserta didik lulus $\mathrm{KKM} /$ tuntas atau $94 \%$ peserta didik mendapat nilai di atas KKM (82) dan 2 peserta didik tidak lulus $\mathrm{KKM} /$ tidak tuntas. Berdasarkan hasil penelitian tersebut dapat disimpulkan bahwa terdapat peningkatan kemampuan siswa menulis resensi novel setelah dibelajarkan dengan menggunakan metode peta pikiran.
\end{abstract}

\section{A BS TRACT}

Reviewing a novel is one of the teaching materials taught to practice writing skills and increase student interest. It is just that not all students can review novels well. This research aims to improve student's learning outcomes by writing novel reviews using the mind map learning method. This research is a classroom action research conducted in two research cycles. Each research cycle consists of four stages: planning, action implementation, observation, evaluation, and reflection. The subjects involved in this study were 32 students of class XI SMA. Data collection in the study was carried out using the methods of observation, interviews, questionnaires, and tests. The research instrument is an observation sheet and a student's writing ability test sheet. The data obtained in this study were analyzed using a qualitative descriptive analysis technique using the percentage formula. The results obtained in this study indicate that in the first cycle, as many as 17 students passed the $K K M$ / completed or $53 \%$ of students scored above the KKM (82), and 15 students did not pass the $K K M$ / incomplete because they got scores below the KKM score (82). Thus, the indicators of success have not been achieved, so it needs to be continued in cycle II. The results of the second cycle showed that of the 32 students who took the test, 30 students passed the KKM/completed or $94 \%$ of the students scored above the KKM (82), and two students did not pass the KKM/uncompleted. Based on the results of this study, it can be concluded that there is an increase in the ability to write novel reviews of students after being taught using the mind map method. 


\section{PENDAHULUAN}

Menulis merupakan suatu keterampilan berbahasa yang dipergunakan untuk berkomunikasi secara tidak langsung (Damanik \& Tansliova, 2020; Sukirman, 2020). Menulis merupakan kegiatan yang produktif dan ekspresif (Erviana et al., 2021; Putri et al., 2021). Menulis pada dasarnya merupakan salah satu keterampilan bahasa yang tidak lepas dalam pendidikan. Pembelajaran menulis bertujuan untuk mengembangkan kemampuan siswa dalam mengungkapkan pikiran, pendapat, gagasan, dan perasaan dalam berbagai ragam tulisan sastra maupun nonsastra (Ansoriyah \& Rahmat, 2018; Ruspa, 2019). Melalui kegiatan menulis, segala informasi, ilmu pengetahuan, dan berbagai kecakapan yang diperoleh tidak sekadar hafalan yang mudah dilupakan sesaat (Fitriana, 2019; Muhafidin, 2018). Salah satu keterampilan menulis yang dapat melatih peserta didik untuk menjelaskan ide, gagasan, atau pikiran dalam bentuk tulisan adalah keterampilan menulis resensi (Alawia, 2019; Pratiwi et al., 2021; Safitri et al., 2021; Sukirman, 2020). Ide, gagasan, atau tulisan itu bisa berbentuk sebuah resensi (Nurjanah \& Heryana, 2019). Menulis resensi merupakan salah satu upaya memperkenalkan suatu karya atau pembahasan kepada peserta didik lain yang belum membaca atau belum menyaksikannya, sehingga setelah membaca resensi peserta didik tersebut tergerak hatinya untuk menyaksikan atau membaca karya peserta didik lain tersebut (Gadri, 2018; Sumaryanto, 2019; Yogini et al., 2019). Resensi buku merupakan salah satu cara membudidayakan minat baca terhadap buku baru.

Dalam kegiatan pembelajaran berbahasa Indonesia, menulis resensi merupakan salah satu pokok bahasan penulisan kreatif sastra. Menulis resensi bermanfaat agar peserta didik terlatih dalam memberikan penilaian secara kritis terhadap bahan bacaan yang dibacanya (Sapitri, 2020). Menulis resensi adalah kemampuan menuangkan pendapat tentang buku yang telah dibacanya (Ibda, 2020; Nurjanah \& Heryana, 2019). Resensi diklasifikasi menjadi tiga bidang garapan, yakni buku fiksi dan nonfiksi, pementasan seni, seperti film, kaset, tari, drama, serta sinetron, dan pameran seni; baik seni patung atau lukisan. Jadi, dapat disimpulkan bahwa tidak hanya buku nonfiksi, pementasan seni, dan pameran seni juga dapat diresensi, tetapi novel yang merupakan salah satu buku fiksi yang juga dapat dimanfaatkan dalam resensi, terutama resensi karya sastra (Lizawati et al., 2021; Nugraha et al., 2018; Ramaniyar \& Rosanti, 2018). Menulis resensi novel merupakan salah satu materi yang dibelajarkan pada keterampilan menulis Bahasa Indoensia siswa. Karya sastra novel dipilih karena novel sebagai karya fiksi menceritakan berbagai masalah kehidupan manusia dalam interaksinya dengan lingkungan (Rahmayanti \& Arifin, 2020). Kegiatan menulis rensesi novel akan dapat meningkatkan minat baca siswa selain itu kegiatan meresensi juga dapat mengembangkan kemampuan menulis dan berbahasa siswa (Rusli, 2021; Septiani et al., 2021). Hanya saja kenyataan di lapangan menunjukkan bahwa tidak semua siswa mampu untuk menulis resensi novel (Scorpiana, 2020). Membaca resensi novel yang sudah ada tidak terlalu sulit bagi peserta didik. Namun, ketika peserta didik diberi tugas untuk menulis resensi novel maka peserta didik merasa seperti diberikan beban yang sangat berat. Peserta didik menganggap menulis resensi novel adalah sesuatu yang sangat sulit, sehingga mereka malas untuk mencoba menulis.

Kurangnya kemampuan siswa dalam meresensi sebuah novel sejalan dengan hasil observasi yang telah dilakukan di SMA Negeri 1 Singaraja. Hasil observasi menunjukkan bahwa sebagian besar siswa XI MIPA 4 belum mampu meresensi sebuah novel dengan baik, sehingga hasil belajar siswa masih di bawah KKM. Kurangnya kemampuan siswa dalam meresensi sebuah novel cenderung disebabkan oleh kurangnya latihan dan bimbingan dari para pendidik. Selain itu, kurangnya disiplin atau ketegasan pendidik dalam memberi tugas menulis resensi membuat peserta didik tidak sungguh-sungguh dalam mengerjakan tugas. Tidak jarang peserta didik membuat tugas menulis resensi buku dengan cara melihat sinopsis buku yang ada di bagian sampul buku. Faktor waktu dan lingkungan tempat peserta didik belajar juga ikut berpengaruh. Hal ini disebabkan oleh cuaca panas di siang hari dan lingkungan yang berisik dapat membuat peserta didik menjadi malas belajar dan mengantuk. Jika dibiarkan secara terus menerus, masalah ini akan berdampak pada penurunan hasil belajar siswa serta berpengaruh terhadap keterampilan berbahasa lainnya.

Untuk mengatasi masalah tersebut, pendidik harus berupaya untuk meningkatkan keterampilan menulis resensi peserta didik. Masalah tersebut harus mendapatkan penanganan yang tepat. Perlu dicarikan sebuah metode pembelajaran yang menarik dan inovatif untuk mengatasi masalah tersebut. Oleh karena itu, agar kegiatan pembelajaran menjadi lebih menyenangkan, pendidik harus menggunakan model ataupun metode pembelajaran yang dapat menunjang proses pembelajaran. Salah satu metode pembelajaran yang dapat menarik perhatian peserta didik untuk meningkatkan kemampuan menulis resensi novel yaitu metode pembelajaran peta pikiran. Metode peta pikiran merupakan salah satu metode pembelajaran yang berusaha mengoptimalkan kemampuan otak manusia (Aprinawati, 2018; Cemara \& Sudana, 2019; Sarumaha, 2019). Metode ini memungkinkan seseorang dapat memunculkan ide-ide baru, menyusun fakta dan pikiran sedemikian rupa, sehingga cara kerja alami otak dilibatkan sejak awal (Warahmah et al., 2020). Metode pembelajaran ini dirancang untuk mengembangkan kemampuan peserta 
didik dengan kegiatan kreatif menyusun ide-ide pokok sebuah konsep menjadi sebuah peta pikiran yang mudah dipahami oleh peserta didik (Latifah et al., 2020).

Metode pembelajaran peta pikiran (mind map) disajikan dalam bentuk diagram istimewa yang cara kerjanya sesuai dengan cara kerja otak dan yang membantu untuk berpikir, membayangkan, mengingat, dan merencanakan serta menilai informasi (Harfika et al., 2020; Paramita \& Hartati, 2018). Metode peta pikiran akan membantu peserta didik dalam memanfaatkan potensi kedua belah otaknya (Sinulingga \& Juliani, 2016). Adanya interaksi antara kedua belahan otaknya dapat memicu kreativitas peserta didik yang nantinya akan memberikan kemudahan peserta didik dalam proses menulis resensi novel. Proses pembuatan peta pikiran sangat menyenangkan karena sifatnya yang unik sehingga mudah diingat serta menarik perhatian mata dan otak karena di dalam peta pikiran terdapat garis yang berwarna-warni serta gambar-gambar yang menarik. Oleh karena itu, akan memudahkan peserta didik dalam proses pembelajaran menulis resensi novel. Metode peta pikiran akan membantu peserta didik untuk mencari urutan kronologis suatu peristiwa dan kejadian yang diharapkan (Afriyanti, 2020). Peristiwa-peristiwa kecil sampai yang besar yang mendukung sebuah cerita juga dapat diungkapkan dengan serinci mungkin, sehingga apa yang ingin disampaikan dapat tersampaikan dengan baik.

Beberapa penelitian yang telah dilakukan sebelumnya mengungkapkan bahwa terdapat peningkatan hasil pembelajaran menulis teks eksposisi siswa setelah dibelajarkan menggunakan model mind mapping (peta pikiran) (Sarumaha, 2019). Penelitian lainnya juga mengungkapkan bahwa terdapat peningkatan dalam perencanaan, pelaksanaan, dan hasil evaluasi pada keterampilan memproduksi teks cerpen setelah dibelajarkan menggunakan model pembelajaran peta pikiran (mind map) (Bunga, 2018). Penelitian selanjutnya juga mengungkapkan bahwa setelah diterapkan metode pembelajaran Mind Mapping, siswa merasa termotivasi serta mampu menuangkan ide atau gagasan dan mengembangkannya sehingga kemampuan menulis karangan dapat terkembangkan secara optimal (Purwantiningsih, 2019). Berdasarkan beberapa hasil penelitian tersebut dapat dikatakan bahwa penggunaan metode pembelajaran peta pikiran dapat meningkatkan hasil belajar serta keterampilan menulis siswa. Hanya saja pada penelitian terdahulu belum terdapat kajian yang membahas mengenai penggunaan metode peta pikiran untuk meningkatkan kemampuan menulis resensi noven siswa sekolah menengah atas. Oelh karena itu, penelitian ini difokuskan pada kajian tersebut dengan tujuan untuk meningkatkan hasil belajar menulis resensi novel peserta didik kelas XI MIPA 4 SMA Negeri 1 Singaraja dengan penggunaan metode pembelajaran peta pikiran.

\section{METODE}

Penelitian ini merupakan jenis penelitian tindakan kelas (PTK) yang dilaksanakan dalam dua siklus penelitian. Tiap-tiap siklus penelitian terdiri dari empat tahap penelitian diantaranya adalah perencanaan tindakan, pelaksanaan tindakan, observasi atau evaluasi, serta refleksi. Siklus pada penelitian ini dilaksanakanya sampai tercapainya indikator keberhasilan yang telah ditetapkan. Subjek yang terlibat dalam penelitian ini yakni 32 orang siswa kelas XI MIPA 4 SMA Negeri 1 Singaraja. Pengumpulan data dalam penelitian dilakukan dengan menggunakan metode observasi, wawancara, angket, serta metode test. Instrumen penelitian yang digunakan dalam penelitian ini yakni data tentang pelaksanaan metode peta pikiran diperoleh dengan menggunakan lembar observasi, sedangkan data tentang hasil belajar diperoleh dengan tes akhir siklus berbentuk uraian instrumen tes untuk mengetahui peningkatan kemampuan menulis siswa setelah dibelajarkan dengan menggunakan metode peta pikiran. Data yang diperoleh dalam penelitian kemudian dianalisis dengan menggunakan teknik analisis deskriptif kualitatif yakni menggunakan rumus persentase. Kriteria keberhasilan digunakan sebagai patokan dalam mengakhiri penelitian ini adalah sebagai berikut. Pertama, Indikator kinerja yang berkaitan dengan nilai individu yang diperoleh peserta didik yaitu minimal peserta didik mendapat nilai 82 (nilai KKM). Kedua, Indikator kinerja yang berkaitan dengan peningkatan hasil belajar meresensi novel atau ketuntasan klasikal yaitu minimal $\geq 85 \%$ peserta didik telah memperoleh nilai 82 . Ketiga, Indikator kinerja yang berkaitan dengan keberhasilan pelaksanaan skenario pembelajaran yaitu $\geq 80 \%$ skenario pembelajaran yang dibuat telah dilaksanakan dengan benar. Keempat, Indikator kinerja yang berkaitan dengan proses aktivitas belajar peserta didik telah mencapai $\geq 85 \%$. Dengan tercapainya kriteria keberhasilan yang telah ditentukan di atas, penelitian dihentikan. Siklus tindakan yang mampu mencapai kriteria keberhasilan tersebut sekaligus dianggap sebagai tindakan terbaik. 


\section{HASIL DAN PEMBAHASAN}

Hasil

Penelitian ini diawali dengan pelaksanaan observasi dan wawancara kepada peserta didik sebagai data awal. Selain itu, nilai peserta didik pada pembelajaran menulis resensi novel sebelumnya juga dijadikan pijakan bahwa peserta didik memang memiliki kesulitan dalam menulis. Hasil yang diperoleh pada tahap awal penelitian menunjukkan bahwa rata-rata nilai siswa pada pembelajaran meresensi novel masih berada dibawah rata-rata, sehingga berdasarkan hasil tersebut, penelitian dilanjutkan pada pelaksanaan siklus I. Siklus I dilaksanakan dalam dua kali pertemuan. Pertemuan pertama dilaksanakan pada 14 September 2017 dan pertemuan kedua dilaksanakan pada 19 September 2017. Siklus I menunjukkan nilai rata-rata yang diperoleh peserta didik sebesar 80. Dengan KKM sebesar 82, hanya 17 peserta didik yang lulus KKM dan 15 peserta didik tidak lulus KKM. Dengan jumlah tersebut, dapat dipersentasikan bahwa ketuntasan klasikal sebesar 53\%. Data ini menunjukkan bahwa siklus I belum berhasil. Ketidakberhasilan peserta didik dalam menulis resensi novel pada siklus I disebabkan karena peserta didik masih tampak kesulitan dalam mengembangkan tema dengan menggunakan metode peta pikiran, peserta didik masih kesulitan mengembangkan kata kunci dengan menggunakan metode peta pikiran, serta peseta didik kesulitan dalam mengubah hasil peta pikiran menjadi sebuah narasi. Terlihat pada hasil karangannya yang kurang padu. Kendala-kendala yang dihadapi pada siklus I kemudian diperbaiki pada siklus II. Siklus II dilaksanakan dalam satu kali pertemuan. Pertemuan ini diawali dengan pemaparan hal-hal yang perlu diperbaiki peserta didik dalam menulis resensi novel seperti yang telah direncanakan. Selanjutnya, dilakukan pengambilan data. Berdasarkan hasil observasi, pelaksanaan pembelajaran telah dilakukan oleh pendidik dengan sistematis dan semua langkah pembelajaran telah dilakukan. Pada siklus II hasil observasi terhadap pendidik dan peserta didik menunjukkan bahwa kegiatan pembelajaran telah sesuai dengan harapan. Kekurangan-kekurangan pada siklus I sudah dapat diminimalkan pada siklus II. Hal ini terlihat dari hasil siklus II yang menunjukkan nilai rata-rata yang diperoleh sebesar 87 dari 80. Peserta didik yang lulus KKM sudah sebanyak 30 peserta didik dari sebelumnya hanya 17 peserta didik dan yang belum mencapai KKM sebanyak 2 peserta didik. Persentase ketuntasan klasikal sebesar 94\% dari 87\%. Persentase ketuntasan klasikal ini menunjukkan bahwa penelitian ini sudah melampaui yang diharapkan, yakni $\geq 85 \%$. Dengan kata lain, siklus II ini telah berhasil. Siklus II ini dinyatakan telah berhasil berdasarkan ketuntasan klasikal. Namun, secara individu, masih ada dua peserta didik yang belum dinyatakan berhasil. Walaupun kedua peserta didik ini belum berhasil, mereka telah menunjukkan peningkatan dalam pembelajaran jika dilihat dari nilai yang mereka peroleh pada siklus I dan II.

\section{Pembahasan}

Berdasarkan hasil analisis penelitian dapat dilihat bahwa terjadi peningkatan kemampuan menulis resensi novel peserta didik. Peningkatan kemampuan peserta didik dalam meresensi sebuah novel tidak terlepas dari penggunaan metode pembelajaran peta pikiran. Metode pembelajaran peta pikiran pada dasarnya metode pembelajaran yang menggunakan pengingat visual dan sesorik dalam suatu pola dari ide-ide yang saling berkaitan (Fitriana, 2019; Purwantiningsih, 2019; Warahmah et al., 2020). Ide-ide yang dituangkan dalam peta pikiran disajikan seperti peta jalan yang digunakan untuk belajar (Bunga, 2018; Sarumaha, 2019). Melalui penggunaan peta pikiran anak akan dapat mengingat, mendapatkan ide sebagai media permainan serta menuangkan imajinasi sehingga memunculkan kreatifitas (Pramunita, 2021). Membuat peta pikiran merupakan salah satu cara untuk mengasimilasi konsep-konsep yang telah dipelajari oleh siswa, sehingga pembelajaran yang telah diperoleh menjadi lebih terstruktur dan terorganisasi dengan baik (Aprinawati, 2018). Pembuatan peta konsep akan lebih baik apabila dilakukan dengan menambahkan gambar, symbol, serta kode (Sari et al., 2018). Penggunaan metode peta pikiran dalam pembelajaran menulis sangat cocok digunakan untuk mengarahkan proses menulis resensi siswa. Dalam meresensi sebuah novel, siswa harus menulis mulai dari bagian judul, pembuka, sampai pada penutup (Nurjanah \& Heryana, 2019). Kegiatan meresensi sebuah karya sastra pada dasarnya merupakan suatu upaya untuk memperkenalkan karya sastra atau pembatasan kepada peserta didik lain yang belum membaca atau belum menyaksikannya sehingga setelah membaca resensi peserta didik tersebut tergerak hatinya untuk menyaksikan atau membaca karya peserta didik lain tersebut (Sumaryanto, 2019; Yogini et al., 2019). Resensi buku merupakan salah satu cara membudidayakan minat baca terhadap buku baru. Menulis resensi dapat dijadikan sebagai sarana mencurahkan ide dan gagasan dari peserta didik. Namun, kurangnya latihan dan bimbingan dari para pendidik membuat banyak peserta didik yang tidak bisa membuat sebuah resensi. Penguasaan kemampuan menulis resensi buku sangat diperlukan oleh siswa. Resensi yang baik dan benar dapat memberikan gambaran yang jelas mengenai buku yang diresensi bagi pembaca serta dapat mendorong pembaca resensi untuk turut serta membaca buku yang diresensi. Hasil yang diperoleh pada penelitian ini 
sejalan dengan beberapa hasil penelitian terdahulu yang juga menyatakan bahwa terdapat peningkatan hasil pembelajaran menulis teks eksposisi siswa setelah dibelajarkan menggunakan model mind mapping (peta pikiran) (Sarumaha, 2019). Penelitian lainnya juga mengungkapkan bahwa terdapat peningkatan dalam perencanaan, pelaksanaan, dan hasil evaluasi pada keterampilan memproduksi teks cerpen setelah dibelajarkan menggunakan model pembelajaran peta pikiran (mind map) (Bunga, 2018). Penelitian selanjutnya juga mengungkapkan bahwa setelah diterapkan metode pembelajaran mind mapping, siswa merasa termotivasi serta mampu menuangkan ide atau gagasan dan mengembangkannya, sehingga kemampuan menulis karangan dapat terkembangkan secara optimal (Purwantiningsih, 2019). Berdasarkan hasil penelitian dapat dikatakan bahwa penggunaan metode pembelajaran peta pikiran dapat meningkatkan hasil belajar serta keterampilan siswa dalam menulis resensi.

\section{SIMPULAN}

Penggunaan metode peta pikiran secara signifikan mampu meningkatkan kemampuan siswa menulis resensi novel. Hasil yang diperoleh pada penelitian ini dapat dilihat melaui adanya peningkatan kemampuan menulis siswa di setiap siklus. Selain mampu meningkatkan kemampuan menulis, metode peta pikiran juga mampu meningkatkan aktivitas belajar, sehingga siswa lebih aktif dalam kegiatan pembelajaran.

\section{DAFTAR RUJUKAN}

Afriyanti, N. (2020). Upaya Meningkatkan Kemampuan Peserta Didik Menulis Teks Descriptive Mata Pelajaran Bahasa Inggris Menggunakan Model Mind Mapping. Jurnal Tunas Pendidikan, 2(2), 3245. https://doi.org/10.52060/pgsd.v2i2.244.

Alawia, A. (2019). Penerapan Media Gambar Lingkungan Sekitar dalam Meningkatkan Kemampuan Menulis Karangan Deskripsi di Sekolah Dasar. Pedagogik Journal of Islamic Elementary School, 2(2), 147-158. https://doi.org/10.24256/pijies.v2i2.959.

Ansoriyah, S., \& Rahmat, A. (2018). Peningkatan Kemampuan Menulis Populer Mahasiswa Melalui Pendekatan Whole Language dengan Pembuatan Media Story Board. AKSIS: Jurnal Pendidikan Bahasa Dan Sastra Indonesia, 2(1), 29-46. https://doi.org/10.21009/AKSIS.020103.

Aprinawati, I. (2018). Penggunaan Model Peta Pikiran (Mind Mapping) untuk Meningkatkan Pemahaman Membaca Wacana Siswa Sekolah Dasar. Jurnal Basicedu, 2(1), 140-147. https://doi.org/10.31004/basicedu.v2i1.35.

Bunga, J. (2018). Penerapan Model Pembelajaran Peta Pikiran untuk Meningkatkan Keterampilan Menulis Cerpen Siswa SMK. Jurnal Edukasi Khatulistiwa, 1(2), 153. https://doi.org/10.26418/ekha.v1i2.29520.

Cemara, G. A. G., \& Sudana, D. N. (2019). Pengaruh Model Pembelajaran SAVI Bermuatan Peta Pikiran terhadap Kreativitas dan Penguasaan Kompetensi Pengetahuan IPA Siswa. Jurnal Ilmiah Sekolah Dasar, 3(3), 359. https://doi.org/10.23887/jisd.v3i3.18895.

Damanik, E., \& Tansliova, L. (2020). Pengaruh Model Pembelajaran Kooperatif Tipe TTW tntuk Menulis $\begin{array}{llll}\text { Karangan } & \text { Persuasi. Jurnal }\end{array}$ https://doi.org/https://doi.org/10.36985/artikulasi.v2i1.150.

Erviana, Y., Munifah, S., \& Mustikasari, R. (2021). Peningkatan Kemampuan Menulis Kata dengan APE DADU Cerdas. Jurnal Mentari, 1(2), 94-102. https://jurnal.lppmstkipponorogo.ac.id/index.php/Mentari/article/view/129/169.

Fitriana, A. (2019). Pengaruh Penggunaan Model Mind Map terhadap Kemampuan Menulis Karangan Deskripsi pada Siswa Kelas XI SMA PAB 9 Patumbak Deli Serdang. Jurnal Pendidikan Bahasa Dan $\begin{array}{lll}\text { Sastra Indonesia, 104-115. } & \text { 8(1), }\end{array}$ https://journal.unnes.ac.id/sju/index.php/jpbsi/article/view/24018.

Gadri, H. H. (2018). Pembelajaran Membuat Resensi Drama dengan Teknik Think Talk Write pada Siswa Kelas XI Bahasa SMA Negeri 1 Cileunyi, Bandung. Jurnal Artikula, 1(1), 47-52. https://doi.org/10.30653/006.201811.6.

Harfika, H., Thahir, R., \& Hambali, H. (2020). Pengaruh Metode Mind Mapping terhadap Minat Belajar Biologi Konsep Monera Siswa Kelas X SMA. Binomial, 3(1), 61-72. https://doi.org/10.46918/binomial.v3i1.481.

Ibda, H. (2020). Peningkatan Keterampilan Menulis Resensi Buku Ilmiah pada Mahasiswa Melalui Program Satu Semester Satu Resensi (TUTER TENSI). Disastra: Jurnal Pendidikan Bahasa Dan Sastra Indonesia, 2(1), 1. https://doi.org/10.29300/disastra.v2i1.1998.

Latifah, A. Z., Hidayat, H., Mulyani, H., Siti Fatimah, A., \& Sholihat, A. (2020). Penerapan Metode Mind 
Mapping untuk Meningkatkan Kreativitas pada Pembelajaran Pendidikan Kewarganegaraan. Jurnal Pendidikan, 21(1), 38-50. https://doi.org/10.33830/jp.v21i1.546.2020.

Lizawati, L., Kusnita, S., Herlina, H., Lahir, M., Wulansari, F., Uli, I., Sulastriana, E., Yuniarti, N., \& Hariadi, T. (2021). Pendampingan Menulis Resensi Novel sebagai Upaya Gerakan Literasi Cerdas Di SMPN 6 Sungai Raya Kabupaten Kubu Raya. Jurnal Pengabdian Masyarakat, 5(2). https://doi.org/10.31571/gervasi.v5i2.2421.

Muhafidin. (2018). Pembelajaran Menulis Wacana Deskripsi Siswa Kelas IV Sekolah Dasar. Jurnal Lensa Pendas, 3(September), 44-49. https://doi.org/10.33222/lensa\%20pendas.v3i2.269.

Nugraha, V., Permana, I., \& Permana, A. (2018). Pembelajaran Menulis Resensi Novel Pertemuan Dua Hati Dan Laskar Pelangi Menggunakan Teknik Comparing. P2M STKIP Siliwangi, 5(2), 55. https://doi.org/10.22460/p2m.v5i2p55-61.966.

Nurjanah, S., \& Heryana, N. (2019). Pembelajaran Menulis Resensi Berdasarkan Kurikulum 2013 pada Siswa Kelas X SMK Negeri 3 Pontianak. Jurnal Pendidikan Dan Pembelajaran Khatulistiwa, 8(9), 19. https://jurnal.untan.ac.id/index.php/jpdpb/article/view/35647/75676582935.

Paramita, S., \& Hartati. (2018). Pengembangan Model Mind Mapping Berbantuan Gambar untuk Meningkatkan Hasil Belajar Menulis Paragraf. Joyful Learning Journal, 7(2). https://doi.org/10.15294/jlj.v7i2.24726.

Pramunita, R. N. (2021). Pengembangan Buku Ajar IPA Berbasis Peta Pikiran untuk Melatih Berpikir Kreatif Peserta Didik di Sekolah Dasar. Jurnal Riset Madrasah Ibtidaiyah (JURMIA), 1(1), 40-47. https://doi.org/10.32665/jurmia.v1i1.196.

Pratiwi, V. U., Nofrahadi, Pendri, A., Komalasari, D., \& Sumarwati. (2021). Penilaian Ranah Afektif dalam Bentuk Penilaian Keterampilan Menulis dengan Model Pembelajaran Think Talk Write (TTW) Menggunakan Media Audiovisual pada Siswa Sekolah Dasar. GERAM, 9(1), 30-37. https://doi.org/10.25299/geram.2021.vol9(1).6817.

Purwantiningsih, S. (2019). Penggunaan Metode Pembelajaran Mind Mapping untuk Meningkatkan Kemampuan Mengarang Siswa di Sekolah Dasar. Jurnal Pendidikan Dasar Setiabudhi, 3(1), 19-27. https://stkipsetiabudhi.e-journal.id/jpds/article/view/79/53.

Putri, E., Wulan, S., \& Siahaan, D. (2021). Strategi Pembelajaran Ekspositori terhadap Kemampuan Menulis Karangan Narasi. Jurnal Ilmu Pendidikan (JIP), 2(1), 49-53. https://jurnallp2m.umnaw.ac.id/index.php/JIP/issue/view/63.

Rahmayanti, W., \& Arifin, E. Z. (2020). Analisis Gaya Bahasa dan Nilai Pendidikan dalam Novel Pulang Karya Tere Liye. Diskursus: Jurnal Pendidikan Bahasa Indonesia, 3(01), 77. https://doi.org/10.30998/diskursus.v3i01.6686.

Ramaniyar, E., \& Rosanti, K. (2018). Pengaruh Penerapan Strategi Pembelajaran The Power of Two terhadap Kemampuan Menulis Resensi. Jurnal Pendidikan Bahasa, 7(2), 308. https://doi.org/10.31571/bahasa.v7i2.1009.

Rusli, M. (2021). Bibliobattle Sebagai Sarana Meningkatkan Minat dan Keterampilan Siswa dalam Meresensi Buku di Masa Pandemi Covid-19. Jira: Jurnal Inovasi Dan Riset Akademik, 2(5), 643651. https://doi.org/10.47387/jira.v2i5.128.

Ruspa, A. R. (2019). Penerapan Model Inquiri pada Pembelajaran Menulis Karangan Eksposisi Siswa Kelas VIII SMP Negeri 1 Sabbang Kabupaten Luwu Utara. Jurnal Studi Guru Dan Pembelajaran, 2(3), 210-220. https://doi.org/10.30605/jsgp.2.3.2019.7.

Safitri, T. M., Susiani, T. S., \& Suhartono, S. (2021). Hubungan antara Minat Membaca dan Keterampilan Menulis Narasi Siswa di Sekolah Dasar. Edukatif: Jurnal Ilmu Pendidikan, 3(5), 2985-2992. https://doi.org/10.31004/edukatif.v3i5.1029.

Sapitri, N. Y. dwi. (2020). Pengaruh Penggunaan Model Pembelajaran Snowball Throwing terhadap Keterampilan Menulis Resensi Cerpen Siswa Kelas XI IPA SMA Negeri 9 Kota Jambi. Aksara: Jurnal Ilmiah Pendidikan Bahasa Dan Sastra Indonesia, 4(1), 69. https://doi.org/10.33087/aksara.v4i1.168.

Sari, K. W. M., Margunayasa, I. G., \& Kusmariyatni, N. N. (2018). Pengaruh Model Pembelajaran Kolaboratif Berbantuan Peta Pikiran terhadap Hasil Belajar IPA. International Journal of Elementary Education, 2(3), 246. https://doi.org/10.23887/ijee.v2i3.15964.

Sarumaha, F. (2019). Penerapan Model Mind Mapping (Peta Pikiran) terhadap Keterampilan Menulis Teks Eksposisi Siswa Kelas X IPS SMA Kristen Hosana Medan 2018/2019. Asas: Jurnal Sastra, 8(2). https://doi.org/10.24114/ajs.v8i2.15441.

Scorpiana, R. (2020). Penggunaan Media Permainan (Teka Teki Dadu) untuk Meningkatkan Aktivitas dan Hasil Belajar Menulis Siswa Kelas IX A SMP Negeri 3 Bintan. Jurnal Kiprah, 8(2), 132-142. https://doi.org/10.31629/kiprah.v8i2.1633.

Septiani, D., Maemunah, S., \& Awla, V. (2021). Pelatihan Penulisan Resensi Karya Sastra di SMK Giri Taruna 
2 Bogor. Jurnal Pengabdian Masyarakat, 2(2). https://doi.org/ 10.30651/hm.v2i2.8595.

Sinulingga, A. S., \& Juliani, R. (2016). Pengaruh Model Problem Based Learning Berbantu Peta Pikiran (Mind Map) terhadap Hasil Belajar Siswa. Inpafi (Inovasi Pembelajaran Fisika), 4(3). https://doi.org/10.24114/inpafi.v4i3.5575.

Sukirman, S. (2020). Tes Kemampuan Keterampilan Menulis dalam Pembelajaran Bahasa Indonesia di Sekolah. Jurnal Konsepsi, 9(2), 72-81. https://p3i.my.id/index.php/konsepsi/article/view/42/38.

Sumaryanto, P. (2019). Peningkatan Hasil Belajar Menulis Resensi Buku dengan Model Cooperative Integrated Reading and Composition (CIRC). Bina Manfaat Ilmu: Jurnal Pendidikan, 1(1), 281-304. https://core.ac.uk/download/pdf/267884784.pdf.

Warahmah, M., Mawardi, \& Nurasiah. (2020). Pengaruh Metode Pembelajaran Inkuiri dengan Model Mind Mapping (Peta Pikiran) terhadap Prestasi Belajar Siswa Kelas VII SMP Negeri 13 Banda Aceh. Jurnal Ilmiah Mahasiswa Pendidikan Sejarah, 5(1), 67-76. https://doi.org/10.24815/jimps.v5i1.15083.

Yogini, D. N. S., Nurjaya, I. G., \& Sriasih, S. A. P. (2019). Efektivitas Penggunaan Metode Buzz Group dalam Pembelajaran Menulis Resensi Cerita Pendek di Kelas Xi SMK Negeri 3 Singaraja. Jurnal

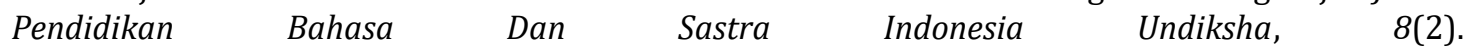
https://doi.org/10.23887/jjpbs.v8i2.20623. 